\title{
GEOTECHNICAL PROPERTIES OF MUNICIPAL SEWAGE SLUDGE
}

\author{
Brendan C. O'KeLLY \\ Lecturer in Civil Engineering \\ Department of Civil, Structural and Environmental Engineering \\ Museum Building, University of Dublin, Trinity College, Dublin 2, IRELAND \\ and formerly Scott Wilson Consulting Engineers, United Kingdom \\ Tel. +353 1608 2387, Fax. +353 1677 3072, E-mail: bokelly@tcd.ie
}

36 page manuscript, comprising 6586 words, one table and 11 figures

\section{Published in the Journal of Geotechnical and Geological Engineering, 2006, Vol. 24, No. 4, 833-850}

First submission: 04 January 2005

Re-submitted: 11 April 2005

\begin{abstract}
The geotechnical properties of municipal sewage sludge, in particular those pertinent to the handling and landfilling of the material, are presented. Index, drying, compaction, shear strength and consolidation tests were conducted on the material at different states of biodegradation. The organic content and specific gravity of solids were found to be inversely related, with typical organic contents of 50-70\% and specific gravity of solids of 1.55-1.80. The density of the compacted material was low in comparison with mineral soils. Standard Proctor compaction yielded a maximum dry density of 0.56 tonne $/ \mathrm{m}^{3}$ at $85 \%$ water content. Laboratory vane-shear and triaxial compression tests indicated that, below about $180 \%$ water content, the shear strength of the sludge material increased exponentially with reducing water content. Consolidated-undrained triaxial compression tests on the pasteurised sludge material indicated an effective angle of shearing resistance of $32^{\circ}$ for the moderately degraded material and $37^{\circ}$ for the strongly degraded material. Biogas was produced at rates of up to 0.33 -litres $/ \mathrm{day} / \mathrm{kg}$ slurry due to ongoing biodegradation and the pore water pressure response must be taken into account in any stress analysis. Consolidation tests using the hydraulic consolidation cell, oedometer and triaxial apparatus indicated that the sludge material was highly compressible although practically impermeable, for example the coefficient of permeability for the moderately degraded slurry was of the order of $10^{-9} \mathrm{~m} / \mathrm{s}$. However, creep deformation was significant with typical coefficient of secondary compression values of $0.02-0.08$ for the compacted material. A more free-draining material was produced at higher states of biodegradation.
\end{abstract}

KEYWORDS: Sewage sludge, geotechnical properties, biodegradation, landfilling 


\section{Introduction}

Sewage sludge is the organic slurry residue derived from wastewater treatment processes. More stringent controls on the quality of wastewater discharges, for example the Council of European Communities (1991) Urban Wastewater Treatment Directive, have given rise to increasing volumes of the sludge. Principal disposal routes include spreading on agricultural land, land restoration, incineration or sludge-to-landfill disposal, either at municipal landfills or sludge monofills. Landfill disposal is currently the principal route for the slurry within the European Community. The slurry must be adequately dried or consolidated to engineer, for example efficient handling and trafficability by machine plant, field compaction and an adequate factor of safety against slope instability of the landfilled material. The slurry is usually allowed to dry naturally in shallow lagoons or consolidated using mechanical presses. The effects of ongoing biodegradation on the shear strength of the sludge material must be considered when calculating the long-term factor of safety against slope instability.

The current knowledge of the geotechnical properties, and in particular the shear strength properties of municipal sewage sludge is limited (Geuzens and Dieltjens, 1991) and was highlighted by the landslide that occurred at the sewage sludge monofill near Deighton, England (Russell, 1992). The geotechnical behaviour of the sludge material is dependent to some extent on the source of the wastewater, and on the type and level of treatment applied. Higher levels of treatment produce a more stable, homogeneous sludge material. Biodegradation processes reduce the organic content with biogas (principally methane and carbon dioxide) and water generated as by-products. Municipal sewage sludge material largely comprises organic particles that are finer than $10^{-4} \mathrm{~m}$, with a significant proportion of these particles in the colloidal range of $10^{-6}-10^{-9}$ $\mathrm{m}$ (Campbell et al. 1978). Organic contents can range from 45-55\% for the strongly degraded material to about $70 \%$ for the raw sludge (Imhoff et al., 1971). The specific gravity of solids is typically 1.4-2.1 (Campbell et al., 1978) and the $\mathrm{pH}$ of the leachate is typically 6.6-7.4.

The geotechnical aspects of municipal sewage sludge monofills were discussed by O'Kelly (2004) and the consolidation properties of the sludge material were reported by O'Kelly (2005). The sludge material was highly compressible although settlement of the landfilled material would occur gradually over a long period of time since the material was practically impermeable. Some undrained shear strength-water content data were reported by Geuzens and Dieltjens (1991). In water treatment literature, the shear strength of the sludge material is often assessed in terms of its solids content SC, defined as the ratio of the mass of the dry solid particles to the bulk sludge mass, expressed as a percentage. Casey (1991) reported that depending on the wastewater source and the level of treatment applied, the solids content of the sludge material necessary for co-disposal with other solid waste in municipal landfills could vary between 15 and $50 \%$. In this paper, the amount of water in the sludge material was quantified using the geotechnical definition of water content $w$, defined as the ratio of the mass of the pore water to the mass of the dry solid particles, expressed as a percentage. The water content was determined on the basis of the oven dry mass corresponding to an oven temperature of $60{ }^{\circ} \mathrm{C}$ instead of the standard drying 
temperature of $105{ }^{\circ} \mathrm{C}$ in order to prevent charring of the organic particles. The water content and solids content values can be related as follows:

$$
S C=\frac{100}{1+\left(\frac{w}{100}\right)}
$$

The consolidated sludge is a soil-like material, and as such, its performance in a landfill can be modelled using soil mechanics theory once the drying, shear strength and consolidation properties of the compacted material are known. The geotechnical and drying properties of municipal sewage sludge of various consistencies and at different states of biodegradation were determined using standard soil laboratory test methods. Index tests, which characterize to some extent the engineering behaviour of the material; standard Proctor compaction; shear strength and consolidation tests were conducted. Full descriptions of the laboratory test methods are given by Head (1992, 1994, 1998). Biogas can become trapped in the landfilled material and may cause a significant build up in the pore water pressure, which may ultimately lead to slope instability. For example, the landslide that occurred at the Deighton sludge monofill was largely attributed to the reduction in the shear strength of the material caused by a build up in the pore water and pore gas pressures (Russell, 1992). Hence, bioactive and neutralized material was tested in order to study the effects of ongoing degradation in the landfill body on the geotechnical properties of the sludge.

\section{Wastewater treatment processes}

Samples of sewage sludge were obtained from Tullamore municipal wastewater treatment plant (Ireland), which serves an urban population of about 12,000. The treatment plant had no significant industrial wastewater influent. The final treatment stage involved biodegradation of the slurry in a bioreactor using the anaerobic, activated sludge digestion method (Metcalf and Eddy, 1991). The slurry in the bioreactor was maintained at about $35{ }^{\circ} \mathrm{C}$, the optimum temperature for mesophilic digestion (Kilmartin, 1991). It is generally very difficult to consolidate the sludge material in practice. The addition of polyelectrolytes to the degraded slurry encouraged flocculation of the solid particles and facilitated dewatering to about $720 \%$ water content using a belt filter press. The slurry material produced a strong odour when agitated.

\section{Index and physical properties}

Some physical and index properties of the black slurry direct from the treatment plant are listed in Table 1. The plasticity characteristics, assessed using the Atterberg limit tests, indicated a liquid limit of $315 \%$ (measured using the cone penetrometer method) and a plastic limit of $55 \%$. The plasticity index of $260 \%$ was calculated as the difference between the liquid limit and plastic limit values. When wet sieved, about 90 $\%$ of the solid particles by dry mass passed the $425-\mu \mathrm{m}$ sieve size. Material retained on this sieve comprised fibrous organic particles, grit and shredded plastic. X-ray 
diffraction analysis indicated that the mineralogy of the inorganic clay fraction comprised quartz, calcite and kaolinite. The very high liquid and plastic limit values and colloidal activity (the plasticity index to clay fraction ratio) were similar in some respects to those of highly humified peat (Skempton and Petley, 1970). Comparable liquid and plastic limit values have also been reported by Miura et al. (1985) and Wang et al. (1992) for water treatment sludge and by Charlie (1977) for paper mill sludge. Ignition of the dry powdered sludge material in a muffle furnace at a temperature of 440 ${ }^{\circ} \mathrm{C}$ produced a $70 \%$ reduction in the mass of the test specimen. The ignition loss is an indirect measure of the organic content of the dry specimen mass, which can be used to assess the state of degradation. Based on the Atterberg limits, sieve analysis and high ignition loss, it can be concluded that the sludge material largely comprised organic clay-sized particles and was classified according to the British Soil Classification System as organic clay of extremely high plasticity.

The specific gravity of solids value of 1.55 was measured using the small pyknometer method. Kerosene having a relative density of 0.79 was used instead of distilled water as the density fluid in the pyknometer; otherwise the sludge specimens would have continued to slowly decompose during the tests. The specific gravity of solids value of 1.55 was low in comparison with mineral soils which generally have a value of 2.5-2.7. However, the specific gravity of solids value was consistent with the range of 1.4-2.1 reported for sewage sludge by Campbell et al. (1978). The $\mathrm{pH}$ of 8.0 for the leachate, measured using an electrometric method, was slightly high for biodegraded sewage sludge. However, the specific gravity of solids, ignition loss and $\mathrm{pH}$ values measured were consistent and indicated that only a moderate state of degradation of the sludge material had occurred at the treatment plant.

\section{Drying, compaction and shrinkage properties}

The sludge material dried slowly outdoors at ambient temperatures of $5-15^{\circ} \mathrm{C}$. Slurry material direct from the treatment plant $(\mathrm{w} \cong 720 \%)$ required a period of about two weeks to dry fully when spread in $6 \mathrm{~mm}$ thick layers. A greasy residue sometimes formed on the surface of the dried material. The water content of the test material was controlled by varying the duration of the drying period. Figure 1 shows separate plots of bulk density and dry density versus water content corresponding to drying and compaction processes. The densities were low overall but were in line with the low specific gravity of solids value measured. Zero air voids curves included in Fig. 1 indicate the upper limit for the dry density that would be achieved if all of the air could be expelled from the material by compaction.

The density produced by air drying of the sludge material at ambient outdoor temperatures (Fig. 1a) was determined from regular mass and volume measurements of cylindrical specimens, initially $38.0 \mathrm{~mm}$ diameter by $76.0 \mathrm{~mm}$ high, which were allowed to slowly air-dry from the liquid limit condition over a period of 30 days. This density-water content data is pertinent, for example to determining the density that can be achieved by allowing the slurry material to air dry in shallow lagoons. 
Compaction tests were conducted on air-dried sludge material using the standard Proctor compactive effort. The test data can be used in the control of the dry density of the material being placed and compacted in layers at a sludge monofill. The storage capacity of the monofill will be optimised by compacting the material to achieve the maximum dry density. The bulk density and dry density values were again low overall but were in line with the low specific gravity of solids value measured for the sludge material. The dry density-water content curve (Fig. 1b) was relatively flat. The maximum dry density of 0.56 tonne $/ \mathrm{m}^{3}$ was achieved at about $85 \%$ water content, referred to as the optimum water content (OWC) for compaction. The material was stiff and compacted poorly, remaining as separate lumps, at water contents below the OWC value. As the water content was increased, the material became more workable and greater levels of compaction were achieved. The dry density decreased slightly at higher water contents since an increasing proportion of the sludge volume was occupied by water. The bulk density increased from about 0.65 tonne $/ \mathrm{m}^{3}$ for the dry sludge material to 1.10 tonne $/ \mathrm{m}^{3}$ for water contents above the OWC value.

Additional tests were conducted to determine the densities that would be achieved by allowing sludge material that had already been compacted at water contents slightly above the OWC value to air dry. This data is pertinent to the air-drying of sludge material that had already been compacted in the monofill. The test specimens were prepared from sludge material at about $90 \%$ water content that had been standard Proctor compacted. These specimens were allowed to slowly air dry and the density of the material was calculated from the masses and volumes of the specimens that were regularly measured. Significantly higher bulk and dry densities, similar to those achieved by air-drying alone (Fig. 1 (a)) were achieved at water contents below the OWC value.

The shrinkage, swelling and adhesion properties of the sludge material were also studied. The volumetric shrinkage ratio, defined as the change in the volume of the sludge material to its change in water content, was typically 1.34. The linear shrinkage value of $33 \%$ was calculated as the percentage reduction in the length of bars of the sludge material at the liquid limit condition after they had been oven dried at $105{ }^{\circ} \mathrm{C}$. The sludge material stopped contracting at about $10 \%$ water content, usually referred to as the shrinkage limit. Hence, air-drying and consolidation of the compacted material to the equilibrium in-situ water content will cause significant volumetric shrinkage.

The swelling capacity on re-hydrating the dry sludge material, which is sometimes produced in pellet form following thermal drying processes, was also studied. Free swell tests, which measure the percentage increase in the volume of the unconfined, dry powdered sludge material after it had been pluviated through water (Holtz and Gibbs, 1956) indicated that full re-hydration would cause the volume of the dry material to approximately double. However, re-hydration of the sludge material occurred very slowly. Compaction tests also showed that the dry sludge pellets compacted poorly since the pellets remained as separate particles.

The lowest water content at which the moist sludge material adhered to metal tools, often referred to as the sticky limit, occurred for about $95 \%$ water content. The sticky limit value was measured as the lowest water content at which the sludge particles 
adhered to a clean dry spatula when the spatula was drawn over the surface of a moist pat of the sludge material. Handling and landfilling of the material may prove more difficult above about $95 \%$ water content due to the tendency of the sludge material to cling to the machine plant.

\section{Undrained shear strength properties}

The undrained shear strength properties were measured using unconsolidated-undrained triaxial compression tests on $38.0 \mathrm{~mm}$ diameter by $76.0 \mathrm{~mm}$ high specimens, and the laboratory vane apparatus using a cruciform vane $12.7 \mathrm{~mm}$ long by $12.7 \mathrm{~mm}$ wide. The undrained shear strength data is pertinent to handling of the sludge material, trafficability at the monofill and achieving an adequate factor of safety against slope instability during landfilling. Sludge specimens of liquid to very stiff consistencies were tested.

Material that had been allowed to air-dry naturally to a water content slightly above the OWC value was standard Proctor compacted in the one-litre compaction mould. Three $38.0 \mathrm{~mm}$ diameter triaxial specimens were prepared from each of the compacted specimens. The water contents of some of these triaxial specimens were reduced below the OWC value before shearing by allowing the specimens to slowly air dry. The undrained shear strength properties of these specimens are characteristic of sludge material that had been allowed to air dry and consolidate in-situ after placing and compacting the material near to the OWC value in the monofill. The air void content of the vane and triaxial specimens was about $5 \%$.

An all-round confining pressure of $100 \mathrm{kPa}$ was applied to the triaxial specimens before shearing under undrained conditions at an axial compression rate of $1.6 \% \mathrm{strain} / \mathrm{min}$. Typical stress-strain data shown in Fig. 2 were characteristic of normally consolidated clay. The undrained shear strength-water content data from the vane-shear and triaxial compression tests summarized in Fig. 3 shows the usual behaviour of the shear strength increasing exponentially with reducing water content. Test specimens wetter than $180 \%$ water content had negligible shear strength. The shear strength data in Fig. 3 corresponds to the shear stress mobilized at $20 \%$ axial strain.

The undrained shear strength measured in triaxial compression was only marginally lower than that measured using the laboratory vane apparatus and good agreement was obtained overall between the two sets of data. Hence, vane shear measurements can provide a quick, reliable measure of the consistency of the sludge material and can be used in practice to assess whether the material has been adequately dewatered for efficient disposal.

\section{Dewatering and consolidation properties}

Under a sustained load, for example due to the landfill overburden, the sludge material will undergo a reduction in volume due to the extrusion of leachate. The rate of consolidation is controlled by the intrinsic permeability of the sludge material. The 
consolidation properties were studied using the oedometer apparatus and the triaxial consolidation apparatus. The duration of the consolidation tests was extended from the standard 24 hours to a period of at least 48 hours to facilitate assessment of the longterm compressibility of sludge monofills. The applied consolidation stresses ranged from only $3 \mathrm{kPa}$ for the slurry material to $400 \mathrm{kPa}$ for the dried compacted material. A load increment ratio of unity and two-way vertical drainage conditions were used for the oedometer tests. Biodegradation of the material may be hindered in practice, for example by the presence of heavy metals from industrial wastes that may become mixed with the landfilled sludge material. Hence, consolidation tests were also conducted on biologically neutralised specimens that had been prepared in the laboratory.

Single and multiple increment oedometer tests were conducted on the slurry material (w $\cong 720 \%$ ) direct from the wastewater plant. The single increment test was conducted on a specimen $76.2 \mathrm{~mm}$ diameter by $19.0 \mathrm{~mm}$ high (Fig. 4 (a)) while multiple increment tests were conducted on a specimen $101.6 \mathrm{~mm}$ diameter by $40.0 \mathrm{~mm}$ high (Fig. 4 (b)). Gas bubbles were seen to slowly escape from the specimens during the tests. Water content tests conducted on horizontal slices of the specimens at the end of the oedometer tests showed that uniform consolidation had occurred over the specimen heights.

Strain-time data from an oedometer tests on a dried compacted sludge specimen, 76.2 $\mathrm{mm}$ diameter by $19.0 \mathrm{~mm}$ high, and triaxial consolidation tests on specimens $38.0 \mathrm{~mm}$ diameter by $76.0 \mathrm{~mm}$ high are shown in Figs. 5 and 6 . The oedometer and triaxial specimens were prepared from one-litre specimens that had been standard Proctor compacted at $100 \%$ water content to achieve a dry density of 0.61 tonne $/ \mathrm{m}^{3}$ and an air voids content of about $5 \%$. The oedometer load stages at 25 and $50 \mathrm{kPa}$ were terminated early since the specimen soon began to swell after consolidating initially, and was probably largely due to the uptake of water by the specimen which was initially in an unsaturated state (5\% air voids). The triaxial specimens were allowed to drain radially and from both ends over a period of 40 days against an applied back-pressure of $340 \mathrm{kPa}$.

The sludge material was highly compressible with large compressive strains usually occurring at a fairly steady rate under the applied load. However, the contributions of the primary consolidation and secondary compression mechanisms in the development of the strains could not be easily separated using standard curve-fitting techniques (Head, 1994). Primary consolidation refers to the compression that occurs due to drainage and hence dissipation of the excess pore water pressures. Secondary compression continues indefinitely due to creep realignment and compression of the solid particles, and in the case of the sludge material, a significant contribution due to ongoing biodegradation of the organic particles after the excess pore water pressure has virtually dissipated.

Based on the shapes of the early part of the strain-time curves (Figs. 4-6), it appeared that primary consolidation had occurred fairly rapidly but generally constituted only a minor part of the overall strain response. Secondary compression was by far the dominant mechanism. The rates of secondary compression were very high in comparison with mineral soils and were also stress-level dependent, as evident from the 
increasing gradients of the oedometer curves with increasing levels of applied stress. Typical values of the coefficient of secondary compression, defined as the axial strain that occurred over one log cycle of time, increased from 0.02 to 0.06 over the stress range of $50-400 \mathrm{kPa}$ during the oedometer tests, and from 0.05 to 0.08 over the effective stress range of $105-210 \mathrm{kPa}$ during the triaxial consolidation tests. The compression-time behaviour was consistent with the high proportion of organic claysized particles that were present in the sludge material and which tended to trap the pore water. A similar compression-time behaviour was also reported by Hobbs (1986) for peat.

The coefficient of permeability of the slurry material was estimated to be of the order of $10^{-9} \mathrm{~m} / \mathrm{s}$ from Terzaghi's theory of consolidation and analysis of the first load step at 3 kPa (Fig. 4 (b)) using standard curve-fitting techniques (Head, 1994). The permeability of the sludge material decreased significantly with increasing effective stress and quickly rendered the material impermeable for practical purposes.

The applied stress-strain-time data from the consolidation tests are traditionally presented in the form of void ratio-log effective stress (e-log $\sigma$ ) plots (Fig. 7). The void ratio is defined as the ratio of the volume of the void space to the volume of the dry solid particles. The slope of the e-log $\sigma$ curve, defined as the compression index $\mathrm{C}_{\mathrm{c}}$, relates directly to the compressibility of the material and is used in design to estimate the total consolidation settlement that would occur in the field. The compression index was found to be stress-level dependent with typical values of $\mathrm{C}_{\mathrm{c}} \cong 7.0$ for the slurry material and $\mathrm{C}_{\mathrm{c}} \cong 0.35$ for the dried compacted material.

\section{Effects of ongoing biodegradation on geotechnical properties}

\subsection{Specific gravity and density}

The effect of higher states of biodegradation (quantified in terms of the ignition loss values) on the specific gravity of solids was studied. Ongoing degradation breaks down the volatile organic particles in the sludge material, increasing the proportion of denser mineral particles and in turn the specific gravity of solids value. Slightly higher bulk and dry densities are also produced due to the increase in the specific gravity of solids.

Specific gravity of solids and ignition loss tests were periodically conducted on slurry material that had been stored outside in drums and allowed to biodegrade at ambient temperature. Sludge specimens were tested direct from the treatment plant and again after a period of three, four and 30 months storage, and finally after ten years storage (Fig. 8). The specific gravity of solids had increased from 1.55 to 1.80 and the ignition loss had reduced significantly from 70 to $50 \%$ after ten years of biodegradation. Hence, biodegradation would occur slowly in the field and would continue to occur beyond ten years. The alkalinity of the test material also reduced slightly with the $\mathrm{pH}$ of the leachate reducing from 8.0 to between 7.6 and 7.8.

Specimens of strongly degraded material that had been produced in the laboratory, and specimens of different municipal sewage sludge from Wessex (England) were also 
tested. The strongly degraded material was produced by further biodegradation of the slurry material from the Tullamore wastewater plant. Two and a half litres of the slurry material ( $\mathrm{w} \cong 510 \%$ ) was poured into a $250 \mathrm{~mm}$ diameter hydraulic consolidation cell. The consolidation cell was assembled and placed in a drying oven. The oven temperature was gradually increased and maintained at $35^{\circ} \mathrm{C}$, the optimum temperature for mesophilic biodegradation (Kilmartin, 1991). Biogas evolved from the specimen at a steady rate of 0.33 -litres/day $/ \mathrm{kg}$ of slurry material. The consolidation cell remained in the drying oven for a period of 21 days after which the oven temperature was gradually reduced back to ambient laboratory temperature. In total, 23.7 litres of biogas had evolved over the 21 day period and the initial volume of the specimen had been reduced by 1.3 litres, which was equivalent to a about $33 \%$ reduction of the dry specimen mass. More strongly degraded test material with specific gravity of solids of 1.72 and an ignition loss of $55 \%$ was produced in this manner.

The specific gravity of solids values measured for the sludge material were within the range of 1.4-2.1 reported by Campbell et al. (1978). Furthermore, Fig. 8 indicates that the specific gravity of solids and ignition loss are inversely related.

\subsection{Effective stress shear strength properties}

The effective stress shear strength properties are used to calculate the factor of safety against instability of the monofill slopes for the intermediate and long-term conditions. Moderately and strongly degraded sludge material was tested to study the effects of ongoing biodegradation on the shear strength properties. Samples of moderately degraded material (70 \% ignition loss) were obtained direct from the wastewater plant. The strongly degraded material (55\% ignition loss) was produced by further biodegradation of the slurry material under optimum laboratory conditions.

The slurry material was pasteurised so that the test specimens would remain in a saturated state facilitating accurate measurement of the pore water pressure response. The $250 \mathrm{~mm}$ diameter hydraulic consolidation cell was placed in the drying oven and the oven temperature was gradually increased to $80{ }^{\circ} \mathrm{C}$ over a period of about five hours. The specimen was allowed to swell under undrained conditions inside the consolidation cell against an applied confining pressure of $100 \mathrm{kPa}$. Biogas stopped evolving after the specimen had been maintained at $80{ }^{\circ} \mathrm{C}$ for a period of three hours, which indicated that the specimen had been pasteurised successfully. The oven temperature was then gradually reduced back to ambient laboratory temperature. Sludge cakes were prepared at $130 \%$ water content by consolidating the pasteurised material under an applied confining stress of $100 \mathrm{kPa}$ with the specimen allowed to drain freely to atmosphere. This specimen preparation method was used as triaxial specimens prepared from dried compacted sludge material could not be fully saturated in the triaxial apparatus within a reasonable time frame.

Two sets of three triaxial specimens, $38.0 \mathrm{~mm}$ diameter by $76.0 \mathrm{~mm}$ high, were prepared from the pasteurised cakes of moderately and strongly degraded sludge material. A $38.0 \mathrm{~mm}$ diameter sampling tube was repeatedly pressed into the sludge cakes in order to form triaxial specimens of sufficient height. The effective stress shear 
strength parameters were determined from consolidated-undrained triaxial compression tests and with measurement of the pore water pressure response. Increments of cell confining pressure and specimen back pressure were applied until a back pressure of $240 \mathrm{kPa}$ had been reached at which point a check on the value of Skempton's pore pressure coefficient B (1954) confirmed that the specimens were fully saturated with B $>0.96$. The two sets of specimens were isotropically consolidated in order to achieve mean effective confining stresses of 40,67 and $150 \mathrm{kPa}$. The specimens were allowed to drain radially and from one end. The volumetric strain-time data for the moderately degraded specimens are shown in Fig. 9 (a).

The triaxial specimens were sheared under undrained conditions at an axial compression rate of $0.002 \%$ strain $/ \mathrm{min}$, and with continuous measurement of the pore water pressure response. The axial compression rate was determined from the triaxial consolidation data and was sufficiently slow to allow the pore water pressure to equilibrate throughout the specimen. The deviator stress and pore water pressure responses of the moderately degraded specimens are shown in Figs. 9 (b, c). The deviator stress was corrected for the reinforcing effects of the side drains and the rubber membranes that enclosed the specimens. The effective stress path plots of $t=1 / 2\left(\sigma_{1}-\sigma_{3}\right)$ versus $s^{\prime}=1 / 2\left(\sigma_{1}^{\prime}+\sigma_{3}^{\prime}\right)$ are shown in Fig. 9 (d). The stress paths are characteristic of normally consolidated clay. The failure line of best fit was drawn through the origin and the stress points corresponding to $20 \%$ axial strain at which the specimens were deemed to have failed (Fig. 9 (d)). The effective angle of shearing resistance $\left(\phi^{\prime}\right)$ value for the moderately degraded sludge material of $32^{\circ}$ was calculated using Eq. (2). A slightly higher $\phi^{\prime}$ value of $37^{\circ}$ was calculated for the strongly degraded sludge material. The effective cohesion was zero, which is characteristic of normally consolidated clay.

$$
\operatorname{Sin} \phi^{\prime}=\operatorname{Tan} \alpha^{\prime}
$$

where $\alpha^{\prime}=$ the slope angle of the failure line to the horizontal $s^{\prime}$ axis (Fig. $9(\mathrm{~d})$ ).

The ratio of the shear strength $\left(c_{\mathrm{u}}\right)$ to the mean effective confining pressure at specimen failure $\left(\sigma_{c}^{\prime}\right)$ was 1.1 , and equals that predicted for saturated normally consolidated clay using Eq. (3). Similar $c_{u} / \sigma_{c}^{\prime}$ values were reported by Andersland et al. (1981) for organic soils with comparable ignition losses.

$$
\frac{c_{u}}{\sigma_{c}^{\prime}}=0.11+(0.0037)(P I) \quad \text { (Skempton, 1957) }
$$

where $P I=$ the plasticity index $(\%)$.

Although the $\phi^{\prime}$ values were measured for neutralised sludge material, these values can also be used to analyse the intermediate and long-term factors of safety against slope instability for monofills of bioactive sludge material providing effective biogas control and leachate drainage systems are in place to allow the biogas and leachate to readily escape. 


\subsection{Pore water pressure response due to ongoing biodegradation}

The pore water pressure within the landfill body can build up steadily if provisions for biogas control and drainage of the leachate are deficient. The rate of build up in the pore water pressure was measured for the moderately biodegraded sludge material $(70 \%$ ignition loss) using the hydraulic consolidation cell. Two and a half litres of the slurry material was confined inside the consolidation cell at the ambient laboratory temperature of $21{ }^{\circ} \mathrm{C}$. The valves on the hydraulic line to the cell diaphragm and the specimen drainage lines were closed in order to keep the specimen volume constant. The pressure that was exerted on the cell diaphragm and the pore water pressure response are shown in Fig. 10. The pore water pressure was found to increase steadily at a rate of $42 \mathrm{kPa}$ /day. Furthermore, following from Boyle's Law for gases, the rate of production of biogas, and hence the rate of biodegradation, were found to be independent of the pressure build up. About 6.9 litres of biogas escaped from the hydraulic consolidation cell when the specimen drainage valves were opened.

\subsection{Compressibility and consolidation properties}

Figure 11 shows the compression-time data recorded for specimens $(250 \mathrm{~mm}$ diameter by $45 \mathrm{~mm}$ high) of moderately and strongly degraded sludge material that were consolidated from the slurry state $(\mathrm{w} \cong 720 \%)$ using the hydraulic consolidation cell. The top surfaces of the specimens were allowed to drain freely to atmosphere while the pore water pressure response was measured at the base of the specimens. The degree of consolidation is also shown in Fig. 11 for the strongly degraded specimen. Although the cell confining pressure of $300 \mathrm{kPa}$ applied to the strongly degraded specimen was three times greater than that applied to the moderately degraded specimen, it is still evident from Fig. 11 that consolidation occurred more readily for the more strongly degraded material. An average degree of consolidation of about $50 \%$ was achieved within 20 min for the strongly degraded specimen and the shape of the compression-time curve was more characteristic of the consolidation behaviour associated with mineral soils. Primary consolidation also accounted for a larger proportion of the overall specimen strain and the coefficient of secondary compression value of 0.08 was also significantly lower than the value of 0.41 measured for the moderately degraded specimen. Hence, more thorough biodegradation of the sludge at the wastewater plant would facilitate more efficient mechanical consolidation and lead to higher rates of consolidation occurring in the field.

\section{Summary and conclusions}

The geotechnical properties of municipal sewage sludge are presented in the context of handling and landfilling of the consolidated sludge material. The geotechnical properties were dependent on the state of biodegradation. The specific gravity of solids and the organic content, quantified indirectly in terms of the ignition loss, were inversely related with typical specific gravity of solids of $1.55-1.80$ and organic contents of $50-70 \%$ dry mass. The rate of biodegradation was strongly temperature dependent. For example, the same level of biodegradation of the slurry material from the wastewater plant could be achieved after a two and a half year period at the ambient 
outdoor temperature or after a 21-day period at the optimum temperature of $35{ }^{\circ} \mathrm{C}$. Biodegradation continued to occur beyond a period of ten years for sludge material stored outdoors.

Standard Proctor compaction tests indicated that the maximum dry density of 0.56 tonne $/ \mathrm{m}^{3}$ was achieved at about $85 \%$ water content. The density of the dried compacted material was low in comparison with mineral soils but was in line with the low specific gravity of solids values of 1.55-1.80. Air-drying of the sludge material to the shrinkage limit of $10 \%$ water content caused significant volumetric reductions. The material lost its adhesion below about $95 \%$ water content so that landfilling would be conducted most effectively between 85 and $95 \%$ water contents.

Undrained shear strength-water content data from triaxial compression and vane shear tests indicated that the shear strength increased exponentially with reducing water content. The vane shear test was found to provide a reliable measure of the shear strength. Hence, the test can be used to quickly assess whether the sludge material has been consolidated sufficiently for landfill disposal. The effective stress strength parameters were determined from consolidated-undrained triaxial compression tests on pasteurised sludge material. The effective angle of shearing resistance increased from $32^{\circ}$ to $37^{\circ}$ for the moderately and strongly degraded materials, respectively. The effective cohesion was zero, characteristic of normally consolidated clay. The pore water pressure response due to ongoing biodegradation must be taken into account in stability analysis. Biogas was found to evolve at a steady rate of up to 0.33 -litres $/$ day $/ \mathrm{kg}$ of the moderately degraded slurry material, which caused the pore water pressure to increase by up to $42 \mathrm{kPa}$ /day under undrained conditions.

The sludge material was highly compressible yet practically impermeable, for example the coefficient of permeability of the moderately degraded slurry material was of the order of $10^{-9} \mathrm{~m} / \mathrm{s}$. Secondary compression, which included a significant contribution due to ongoing biodegradation of the volatile organic particles, was dominant. The coefficient of secondary compression values of $0.02-0.08$ measured for the compacted sludge material were very high in comparison with mineral soils. Higher states of biodegradation produced a more free-draining sludge material with a greater proportion of the overall compression occurring as a result of primary consolidation.

\section{Acknowledgements}

The support of Professor Tom Casey and Dr. Tom Widdis is gratefully acknowledged during course of the research, which was conducted for the MEngSc degree at the Department of Civil Engineering, University College Dublin, Ireland. Research awards from the Geotechnical Trust Fund of the Institution of Engineers of Ireland and the Lord Edward Fitzgerald Memorial Fund of University College Dublin are gratefully acknowledged. 


\section{References}

Andersland, O.B., Khattak, A.S. and Al-Khafaji, A.W.N. (1981) Effect of organic material on soil shear strength. In Laboratory Shear Strength of Soil ASTM STP 740 (edited by R.N. Yong and F.C. Townsend), American Society for Testing and Materials, West Conshohocken, PA, pp. 226-242.

Campbell, H.W., Rush, R.J. and Tew, R. (1978) Sludge Dewatering Design Manual, Research Report No. 72, Ontario Ministry of the Environment.

Casey, T.J. (1991) The science and technology of sludge disposal, in Proceedings of Seminar on Sludge Disposal, Dublin, Institution of Engineers of Ireland, Vol. 1, pp. 124.

Charlie, W.A. (1977) Pulp and paper mill solid waste disposal-a review, in Proceedings of Conference on Geotechnical Practice for Disposal of Solid Waste Materials, New York, American Society of Civil Engineers, Vol. 1, pp. 71-86.

Council of European Communities (1991) Directive Concerning Urban Wastewater Treatment (91/271/EEC), Official Publication of the European Communities, L135/40.

Geuzens, P. and Dieltjens, W. (1991) Mechanical strength determination of cohesive sludges - a Belgian research project on sludge consistency. In Recent Developments in Sewage Sludge Processing (edited by F. Colin, P.J. Newman and Y.J. Puolanne), Elsevier, London, pp. 14-23.

Head, K.H. (1992) Manual of Soil Laboratory Testing: (1) Soil Classification and Compaction Tests, Pentech Press, London.

Head, K.H. (1994) Manual of Soil Laboratory Testing: (2) Permeability, Shear Strength and Compressibility Tests, Pentech Press, London.

Head, K.H. (1998) Manual of Soil Laboratory Testing: (3) Effective Stress Tests, Wiley, London.

Hobbs, N.B. (1986) Mire morphology and the properties and behaviour of some British and foreign peats, Quarterly Journal of Engineering Geology, 19(1), 7-80.

Holtz, W.G. and Gibbs, H.J. (1956) Engineering properties of expansive clays, Transactions American Society of Civil Engineers, 121(1), 641-677.

Imhoff, K., Muller, W.J. and Thistlethwayte, D.K.B. (1971) Disposal of Sewage and other Water Borne Wastes, Butterworks, London.

Kilmartin, L. (1991) EC directive constraints on the disposal of sewage sludge, in Proceedings of Seminar on Sludge Disposal, Dublin, Institution of Engineers of Ireland, Vol. 1, pp. 1-24. 
Metcalf and Eddy Inc. (1991) Wastewater Engineering: Treatment, Disposal and Reuse, McGraw-Hill, Singapore.

Miura, N., Fukuda, N. and Kobayashi, Y. (1985) Geotechnical properties of highly moistured wastes and rapid dehydration by a bottom drainage method, Proceedings of Japanese Society of Civil Engineers, 3(358), 157-163.

O'Kelly, B.C. (2004) Geotechnical aspects of sewage sludge monofills, Municipal Engineer, 157(ME3), 193-197.

O'Kelly, B.C. (2005) Consolidation properties of a dewatered municipal sewage sludge, Canadian Geotechnical Journal, (accepted for publication)

Russell, H. (1992) Race to clear sludge landslide, New Civil Engineer, Magazine of the Institution of Civil Engineers, 20th February, pp. 5.

Skempton, A.W. (1954) The pore pressure coefficients A and B, Geotechnique, 4, 143147.

Skempton, A.W. (1957) Discussion on planning and design of the new Hong Kong Airport, in Proceedings of Institution of Civil Engineers, 7, 305-307.

Skempton, A.W. and Petley, D.J. (1970) Ignition loss and other properties of peats and clays from Avonmouth, King's Lynn and Cranberry Moss, Geotechnique, 20(4), 343356.

Wang, M.C., Hull, J.Q., Jao, M., Dempsey, B.A. and Cornwell, D.A. (1992) Engineering treatment of water treatment sludge, Environmental Engineering, 118(6), 848-864. 


\begin{tabular}{|ll|}
\hline Liquid limit & $315 \%$ \\
Plastic limit & $55 \%$ \\
Shrinkage limit & $10 \%$ \\
Plasticity index & $260 \%$ \\
Specific gravity of solids & 1.55 \\
Ignition loss & $70 \%$ \\
Water content & $720 \%$ \\
Void ratio & 11 \\
Bulk unit weight & $10.2 \mathrm{kN} / \mathrm{m}^{3}$ \\
Dry unit weight & $1.3 \mathrm{kN} / \mathrm{m}^{3}$ \\
pH & 8.0 \\
\hline
\end{tabular}

Table 1: Some properties of slurry direct from wastewater plant 


\section{Legends for (11x) Figures:}

(a) Air drying (shrinkage)

(b) Standard Proctor compaction

Figure 1: Density - water content data

Figure 2: Stress - strain data from triaxial compression tests

Figure 3: Undrained shear strength - water content data

(a) Single increment test

(b) Multiple-increment load tests

Figure 4: Oedometer consolidation of slurry $(\mathrm{w} \cong 720 \%)$

Figure 5: Oedometer consolidation of compacted material $(\mathrm{w}=100 \%)$

Figure 6: Triaxial consolidation of compacted material $(\mathrm{w}=100 \%)$

Figure 7: Void ratio - log effective stress data

Figure 8: Specific gravity of solids - ignition loss data

(a) Isotropic consolidation stage

(b) Deviator stress - axial strain data from compression stage

(c) Pore water pressure responses during compression stage

(d) Effective stress path plots

Figure 9: Effective stress shear strength data from triaxial compression tests (70\% ignition loss)

Figure 10: Pressure build up due to biodegradation

Figure 11: Consolidation of slurry material at different stages of biodegradation 


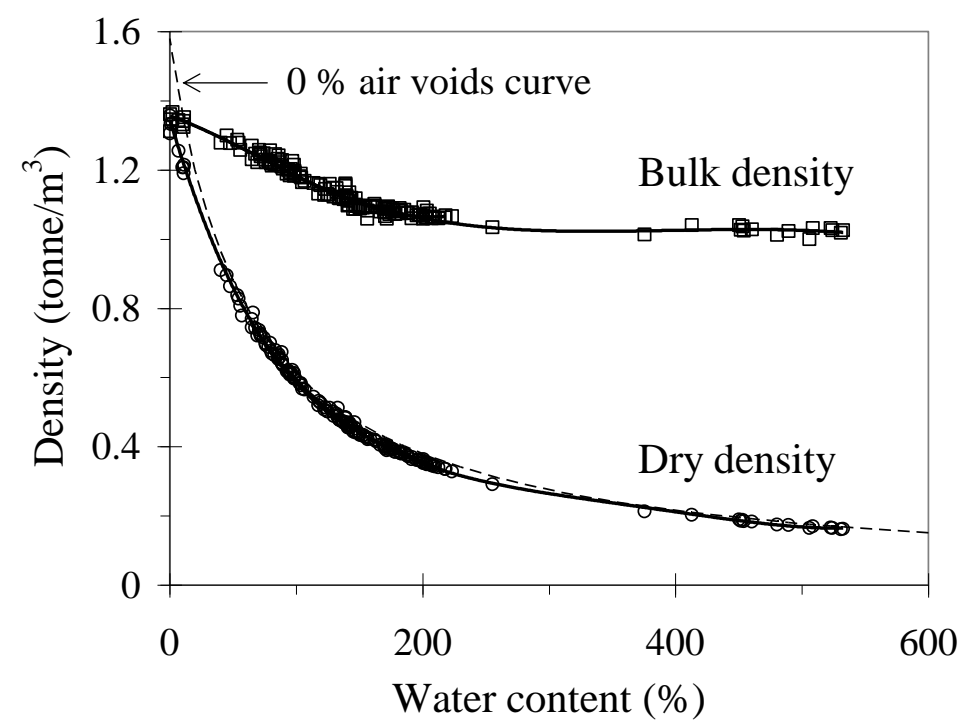

(a) Air drying (shrinkage)

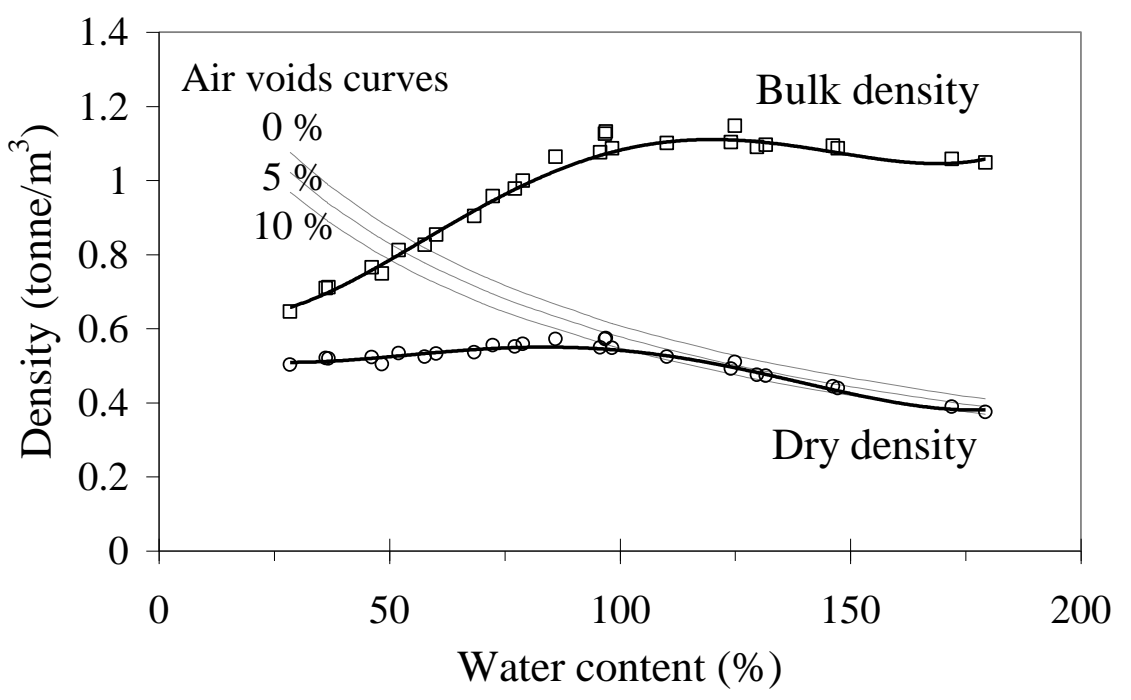

(b) Standard Proctor compaction

Figure 1: Density - water content data 


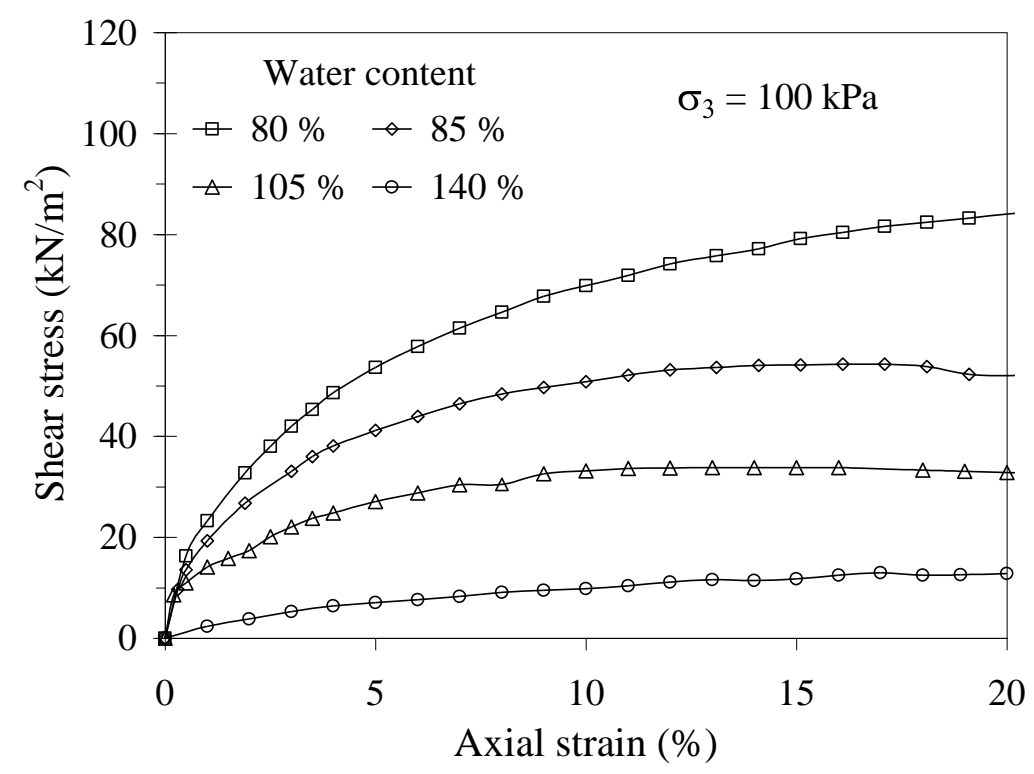

Figure 2: Stress - strain data from triaxial compression tests

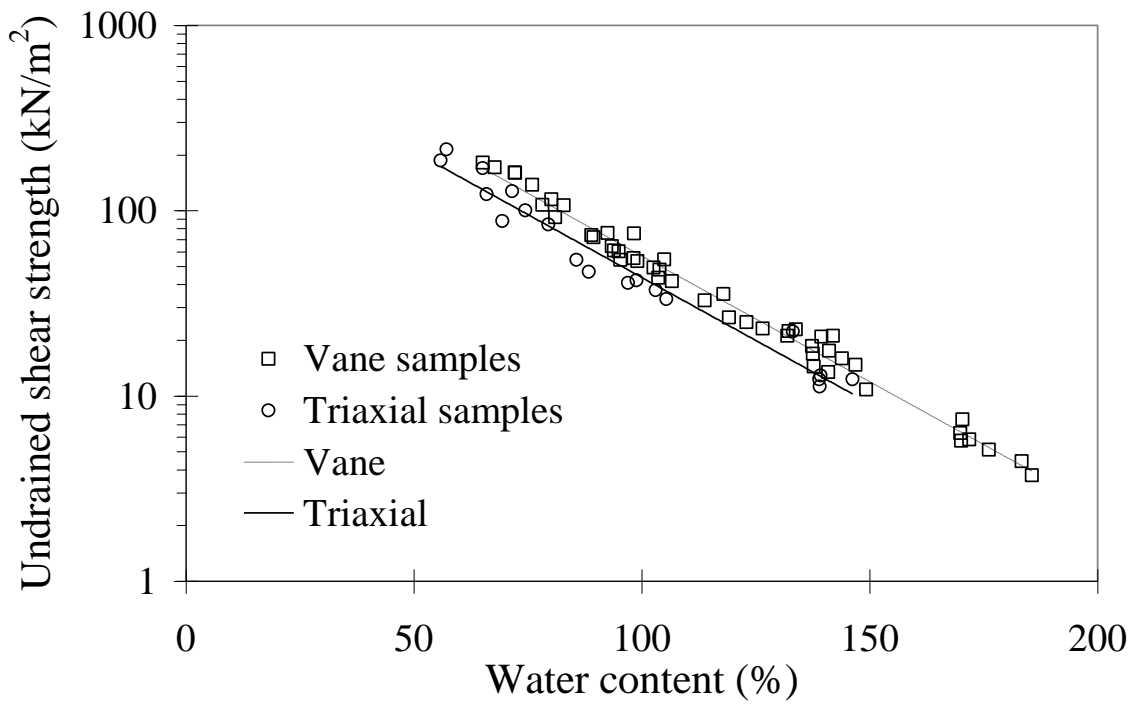

Figure 3: Undrained shear strength - water content data 


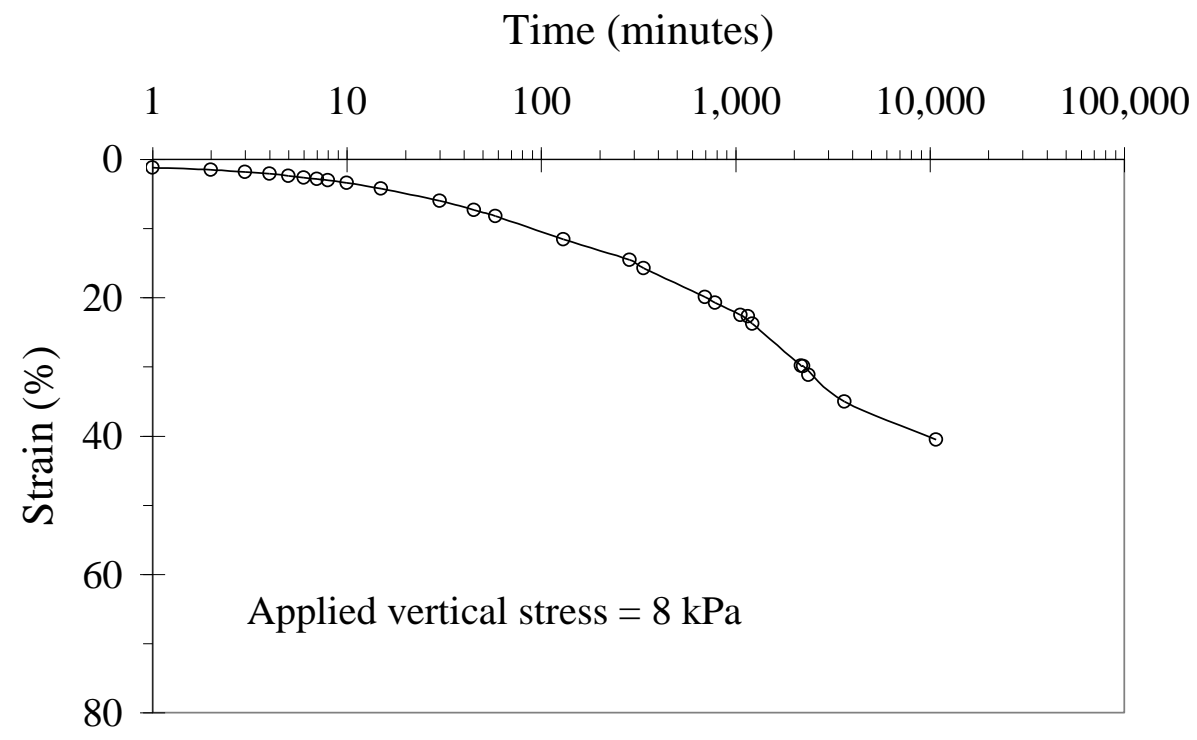

(a) Single increment test

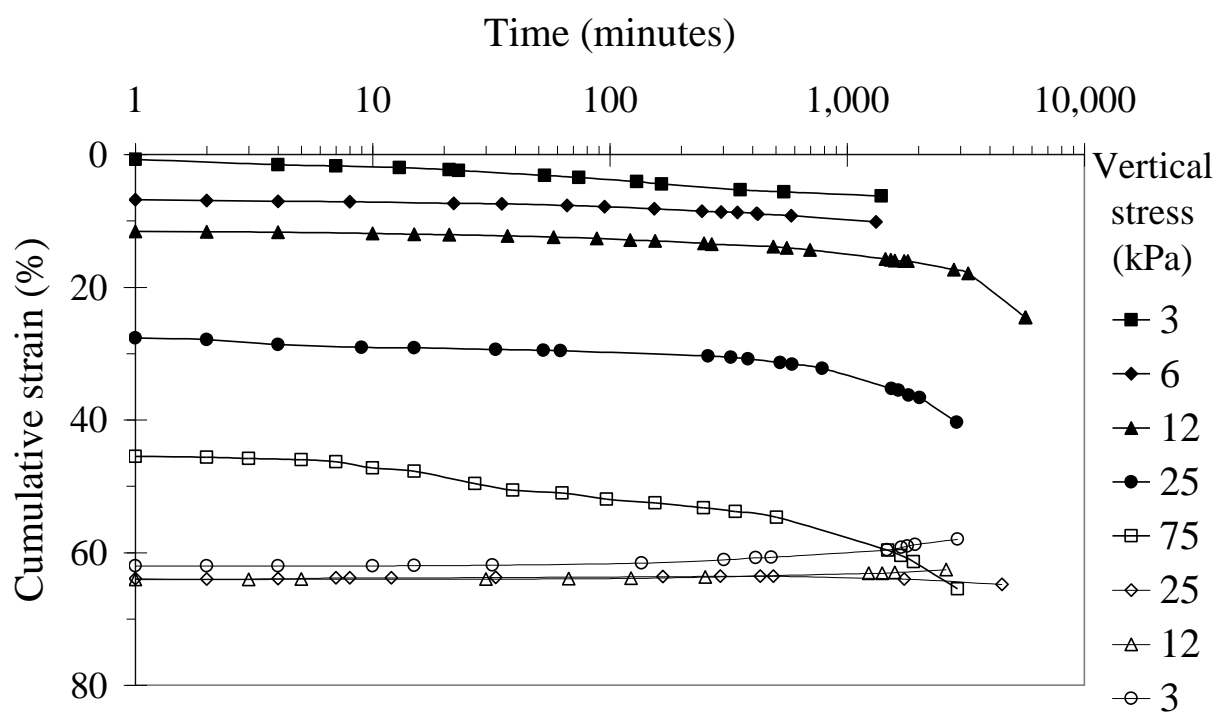

(b) Multiple-increment load tests

Figure 4: Oedometer consolidation of slurry $(\mathrm{w} \cong 720 \%)$ 
Time (minutes)

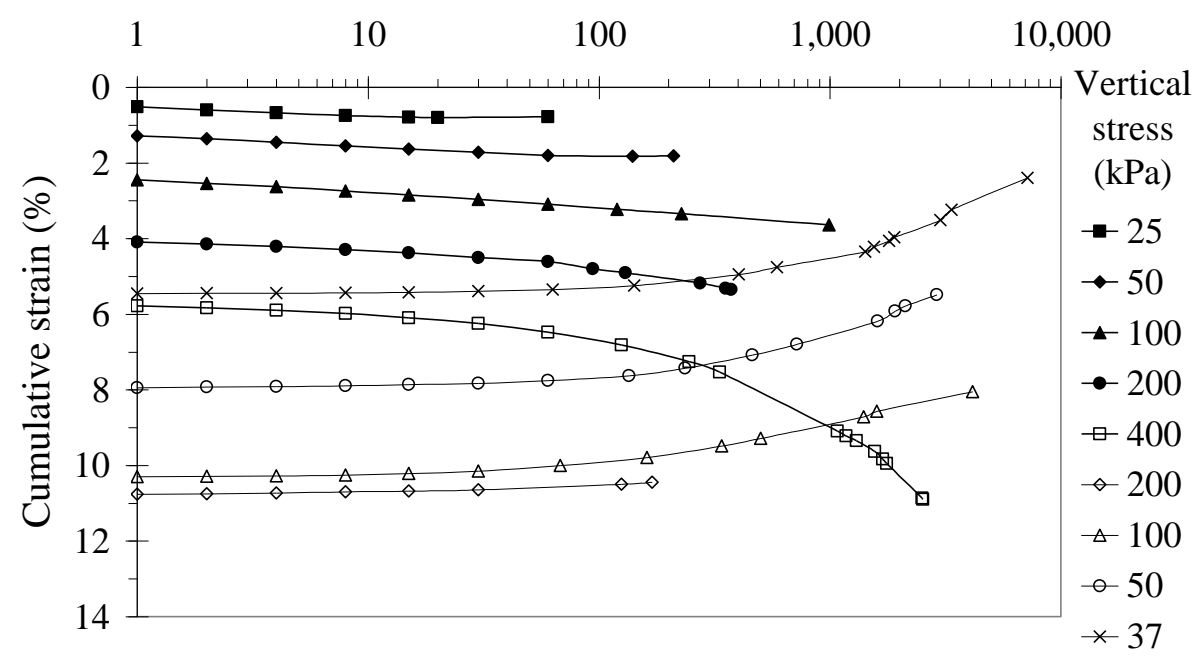

Figure 5: Oedometer consolidation of compacted material $(\mathrm{w}=100 \%)$

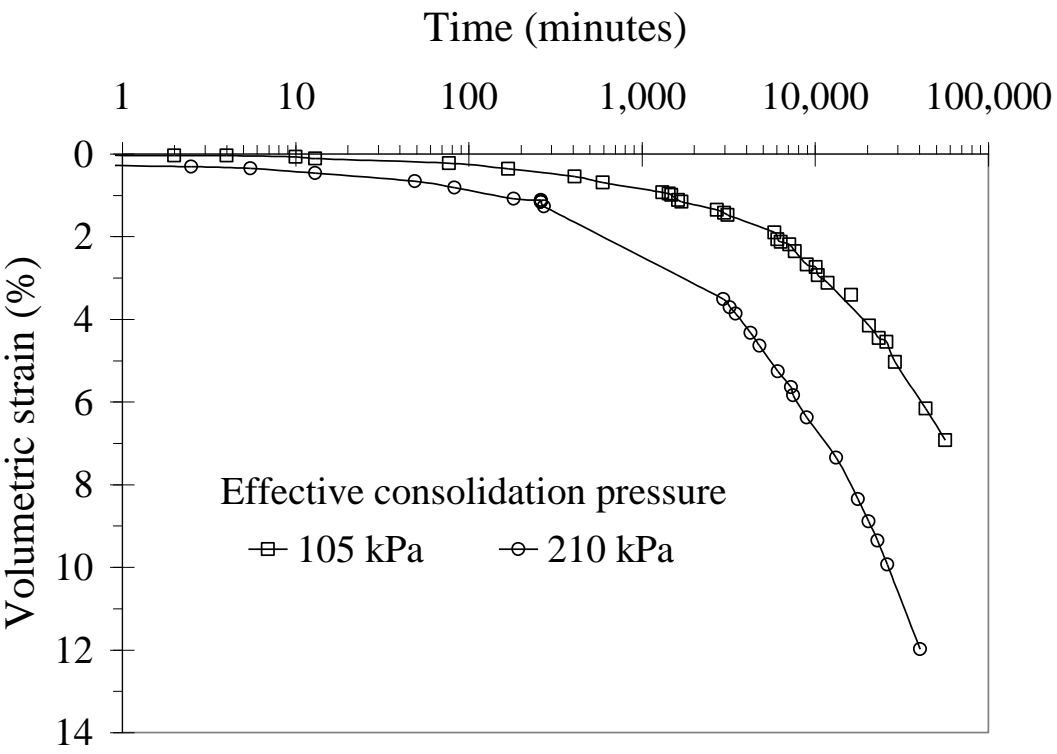

Figure 6: Triaxial consolidation of compacted material $(\mathrm{w}=100 \%)$ 


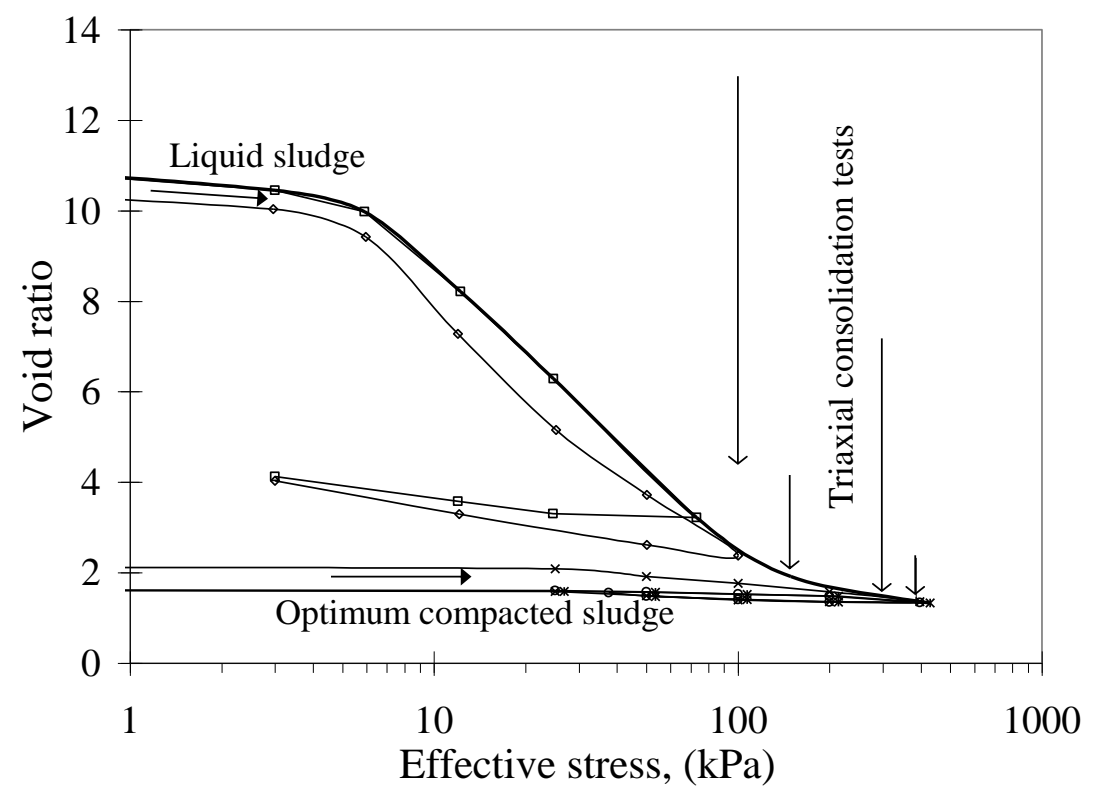

Figure 7: Void ratio - log effective stress data

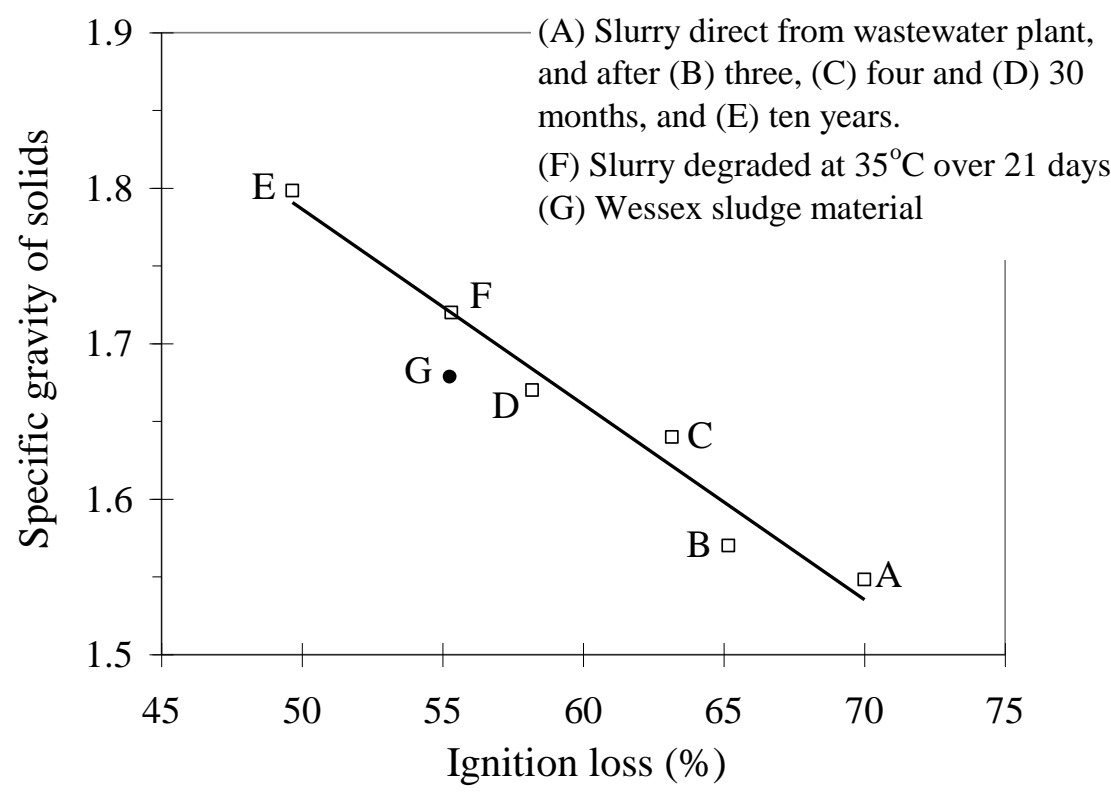

Figure 8: Specific gravity of solids - ignition loss data 
Time (minutes)

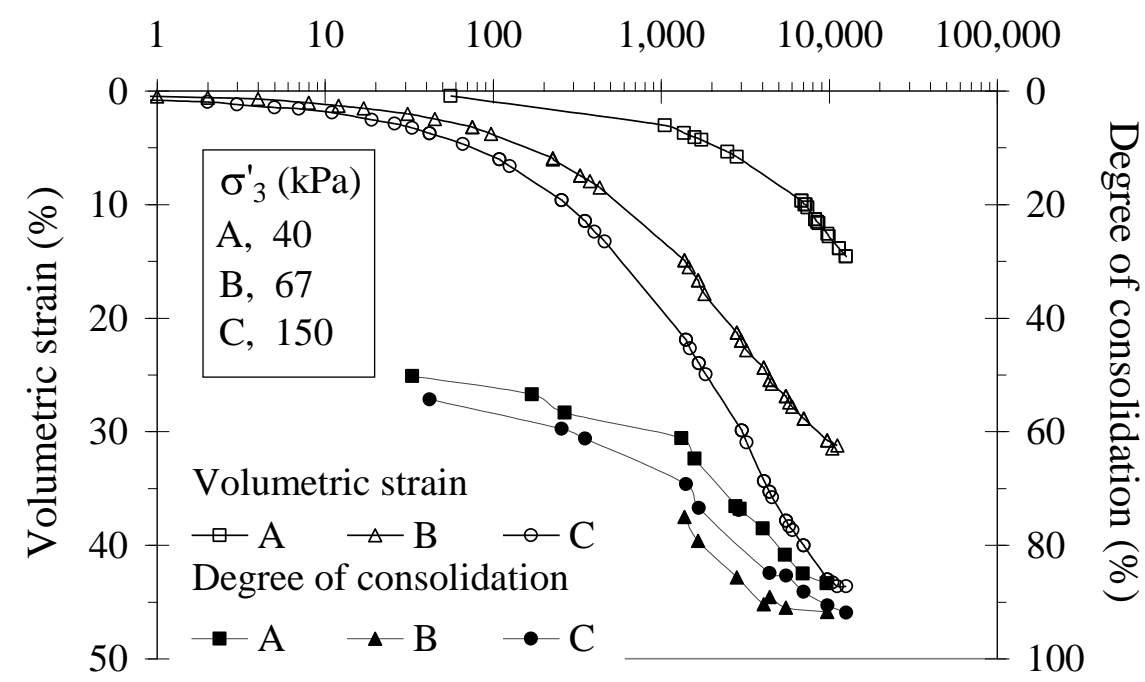

(a) Isotropic consolidation stage

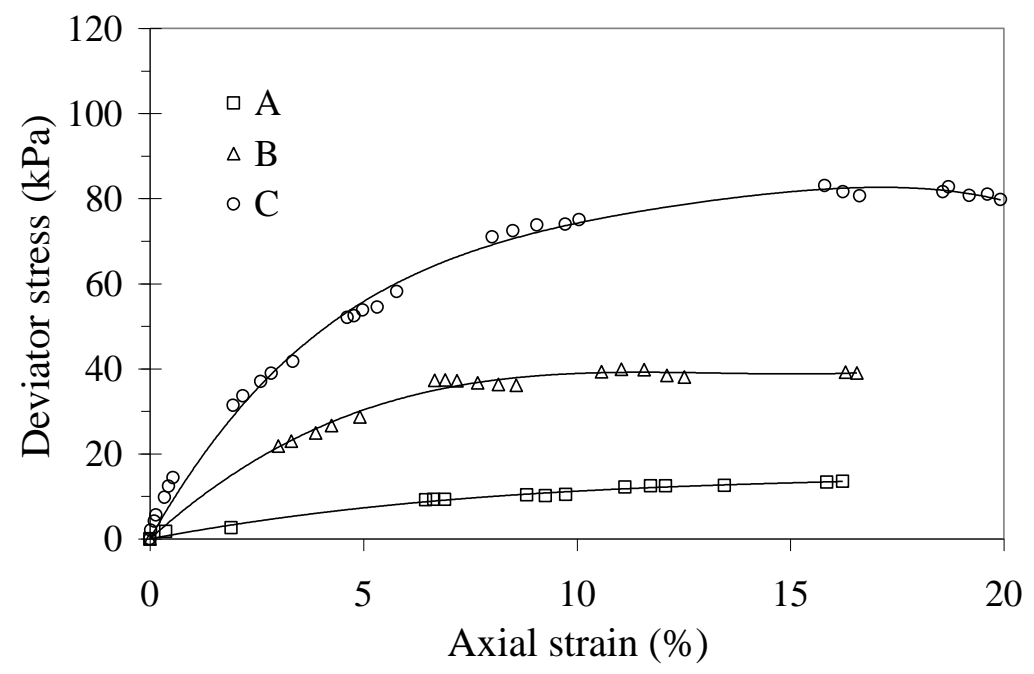

(b) Deviator stress - strain data from compression stage

Figure 9: Effective stress shear strength data from triaxial compression tests (70\% ignition loss) 


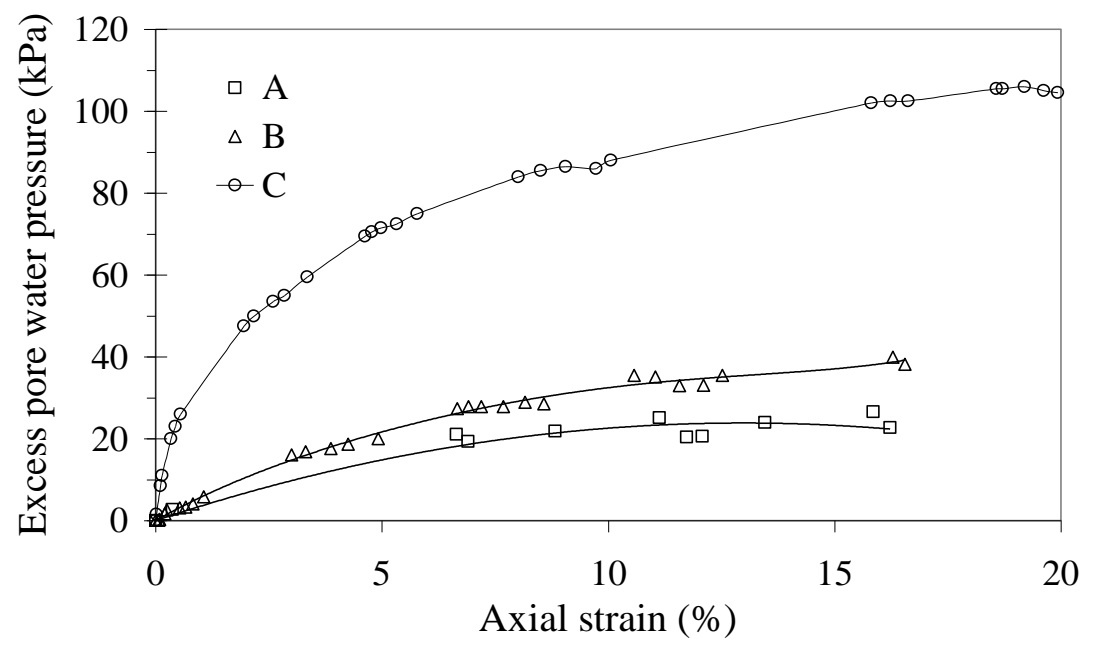

(c) Pore water pressure responses during compression stage

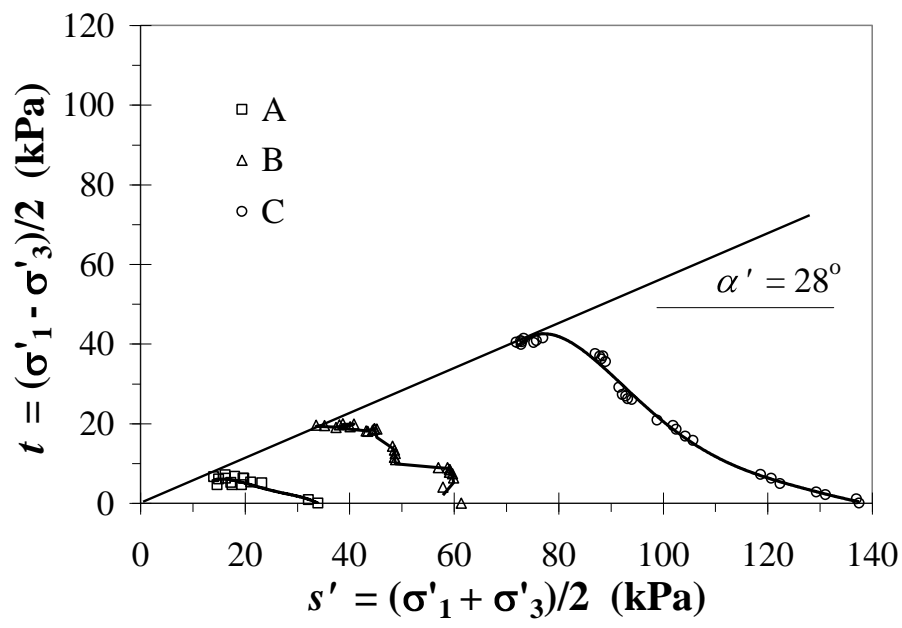

(d) Effective stress path plots

Figure 9 (contd.): Effective stress shear strength data from triaxial compression tests (70 $\%$ ignition loss) 


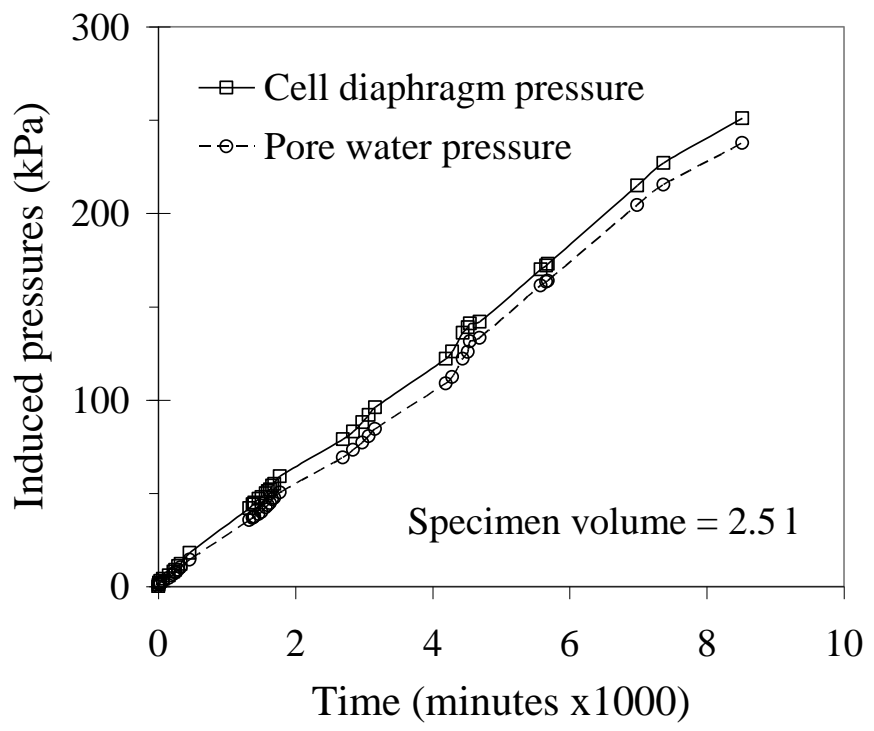

Figure 10: Pressure build up due to biodegradation

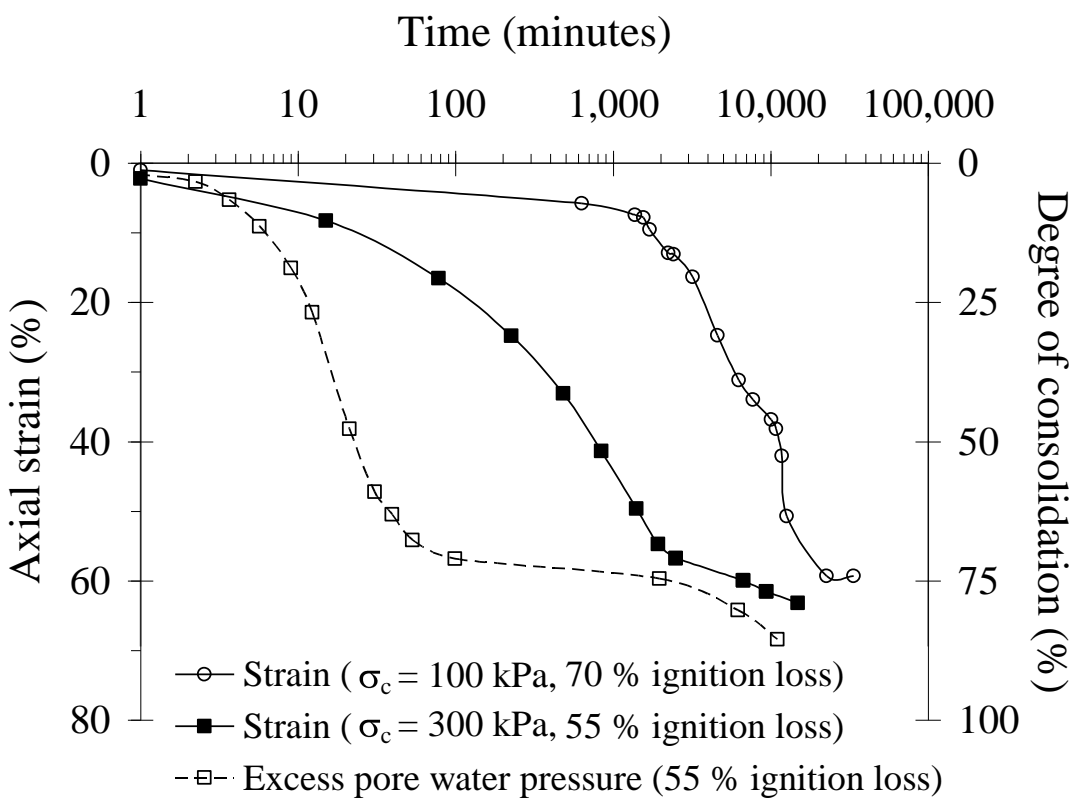

Figure 11: Consolidation of slurry material at different stages of biodegradation 